Слободан Бјелица

Универзитет у Новом Саду

Филозофски факултет

Одсек за историју

sbjelica@eunet.rs
Оригиналан научни рад

примљено: 1. јун 2012

прихваћено: 1. октобар 2012

\title{
СТУДЕНТСКИ ПРОТЕСТ НА НОВОСАДСКОМ УНИВЕРЗИТЕТУ ЈУНА 1968. ГОДИНЕ
}

Сажетак: Бурни протести који су захватили студентску популацију током 1968. године широм света нису заобишли ни социјалистичку Југославију. Прво београдски, а потом и студенти осталих југословенских универзитета ступили су у штрајк и истакли су захтеве за праведнијим односима у друштву. У овом великом протестном покрету, током прве декаде јуна 1968. године, Универзитет у Новом Саду је био на маргинама дешавања. Скупови који су се одржавали по факултетима и студентским домовима у саставу Новосадског универзитета мање су имали протестни карактер, а више су организовани у сврху солидарисања са београдским колегама, али и мерама које је предузимала комунистичка власт. За овакво обележје студентског покрета у Новом Саду заслуге је имала и добро организована акција коју су предузели највиши партијски форуми у Војводини.

Кључне речи: 1968. година, Новосадски универзитет, Савез комуниста, студенти.

Година 1968. била је обележена студентским демонстрацијама до тада невиђених размера у многим светским метрополама, што је имало свој одјек и у Југославији. Студентски протест у Београду, који је трајао десет дана јуна 1968. године, имао је за непосредни повод један баналан догађај - интервенцију милиције због туче на једном концерту 2. јуна увече. Сутрадан, 3. јуна, београдски студенти су ступили у протест а осим осуде насиља милиције изнели су и политичке захтеве, који су пре свега били усмерени против све већих социјалних разлика. Студенти су практично заузели своје домове и факултете, а власт се нашла затечена и неодлучна како да реагује. Масовном протесту су се прикључили и студенти Универзитета у Загребу, односно Љубљани, те је запретила опасност да се уздрма до тада неприкосновена власт. Представници режима су избегавали да примењују силу и покушавали су да ситнијим уступцима умире протестанте, а 9. јуна студентима се обратио и председник СФРЈ Јосип Броз Тито, дајући им за право и позивајући их да

\footnotetext{
* Текст је настао као фазни резултат рада на пројекту Војвођански простор у контексту европске историје (број 177002) Министарства просвете и науке Републике Србије.
} 
се врате својим редовним активностима. Након тога је протест у Београду и окончан, на задовољство студената. Међутим, коловође протеста, поготово из редова професора, наредних година су сносиле последице. ${ }^{1}$

Студентска догађања у Новом Саду током јуна 1968. године била су далеко мањих размера него она по другим универзитетским центрима, тако да их само условно можемо назвати протестом. ${ }^{2}$ Низ састанака и зборова на факултетима, по студентским домовима, чак и једне демонстрације у Новом Саду - били су под контролом добро организованих војвођанских комуниста. Како би спречили да студентски протест добије нежељен ток, по узору на београдски, партијски форуми Универзитета, Покрајине и градова који су имали факултете и више школе дали су задатак својим активистима да се умешају међу високошколце - младе идеалисте, да усмеравају њихово деловање и надгледају ток догађаја. „Говорници су унапред брижљиво одабрани, њихови говори излекторисани, леци благовремено одштампани“ - сведочио је један савременик. ${ }^{3}$ У истом пропагандном правцу деловала су и средства јавног информисања.

Једини дневни лист у Војводини на српском језику, новосадски Дневник, опширно је извештавао како о студентским протестима у Београду, тако и о реакцијама у Новом Саду и широм Војводине. У броју од 5. јуна на насловној страни је објављено да је претходног дана одржано неколико састанака највиших политичких форума у Новом Саду „на којима је дата подршка оправданим захтевима студената и разматрано политичко стање везано за друштвено-економски положај студената у Војводини“. У заједничком саопштењу Председништва и Извршног комитета ПК, Покрајинског извршног већа, Председништва Савеза студената и Универзитетског комитета СК Новосадског универзитета, стоји да „студенти Универзитета у Новом Саду, у уверењу да изражавају и мишљење свих радних људи на Универзитету, имајући у виду нарасле и све више растуће проблеме друштвеног и материјалног положаја студената и поједине проблеме у развоју нашег друштва подржавају захтеве београдских студената који су, после изношења великог броја различитих предлога и раздвајања стварних и оправданих интреса студената од псеудореволуционарних и демагошких ставова, у току јучерашњег дана јасно формулисани...“. ${ }^{4}$ Истовремено је јављено како је Извршно веће Војводине донело одлуку да повећа кредите и стипендије студентима Универзитета у Новом Саду.

Наредних дана Дневник је писао о зборовима који су одржавани по факултетима Новосадског универзитета, на којима су се, поред подршке београдским студентима, обавезно могла чути заклињања на верност политици Савеза комуниста. Нешто радикалнији су били студенти и професори Филозофског факултета, на чијем је збору, одржаном 7. јуна увече у згради факултета, пружена

\footnotetext{
${ }^{1}$ Момчило Митровић, Студентске демонстраиије у Београду 1968. године, у: 1968 - четрдесет година после, Београд 2008, 481-490.

2 Бранка Ћурчић, Новосадска неоавангардна сцена, „,Трибина младих“ и утицаји 1968. године, у: Друштво у покрету, Нови Сад 2009, 74.

3 Ласло Вегел, Компромитоване успомене, у: Шездесет осма-личне историје, Београд 2008, 317.

${ }^{4}$ Дневник, 5. 6. 1968.
} 
пуна подршка захтевима београдских колега, те су „веома оштрим речима критиковане бирократске појаве у друштву, привилегије, друштвена диференцијација, бруталан обрачун милиције са београдским студентима, непредузимање мера против оних који су наредили да дође до овог немилог догађаја“. Овом збору присуствовали су и високи партијски руководиоци - Мирко Чанадановић и други. Без инцидената су протекли и зборови који су били одржавани по студентским домовима. ${ }^{5}$

Прилику да расправљају о тек минулим студентским протестима војвођански партијски руководиоци добили су 11. јуна, када је одржана Проширена седница Председништва и Извршног комитета Покрајинског комитета. ${ }^{6}$ Уводну реч имао је Мирко Тепавац, који је присутне упознао са минулим догађајима. Наводећи да је „наша ситуацији у вези са студентским демонстрацијама у Новом Саду на неки начин протекла у знаку придруживања и рефлектовања појава и догађаја у Београду“, Тепавац је додао да то не значи да „код нас нису постојале сопствене основе за сличне појаве, не значи да су оне просто досељене из главног града и да на нашем тлу и на нашим политичким приликама није било извора и изворишта за сличне појаве и сличне догађаје“. Објашњавајући овај свој закључак, подсетио је на сложеност економске ситуације у Војводини, која је, по његовим речима, у првом кварталу 1968. године била „у најтежем положају у целој Југославији“, прецизирајући да је извоз скоро пао на половину, „да су неке гране производње - и то оне које чине око $60 \%$ укупног индустријског потенцијала у нашој покрајини бележиле огроман пад, рецимо метална индустрија $66 \%$, прехрамбена индустрија 90\% и тако даље“.

У наставку излагања се посебно осврнуо на тешкоће које су погађале главни град покрајине, у коме се налазила највећа концентрација студената у Војводини. Навео је да близу 1/3 запослених Новосађана „живи на минималним или умањеним личним дохоцима“, а новосадски привредни гиганти, пре свега „Победа“, „27. март“ и „Дрвни комбинат“, налазили су се у тешкој материјалној ситуацији. Слично је било и у другим факултетским центрима, пре свега Суботици. Све је то претило да студентски немири прерасту у нешто много опасније по власт: „ако би се пренели на улице - то је била и једна наша процена, да таква могућност постоји и да са таквом могућношћу треба рачунати - ако би код дошло до већих немира, до демонстрација кроз улице у градовима, да би лако могло да се догоди да на улице изађе и већи број радника - не зато да би подупрли студентске захтеве већ поставили своје, што би читаву ситуацију сигурно учинило веома сложеном и што би на свој начин деловало и на развитак догађаја у Београду“.

Управо зато су већ прве вести о студентском протесту у Београду изазвале велику пажњу ПК, на чијем се челу налазио Тепавац. Према његовим речима, одлучено је да се превентивно делује и да се спремно дочекају евентуални протести, те су Универзитетски комитет и Савез студената добили задатак „да са своје стране

\footnotetext{
${ }^{5}$ Дневник, 7. 6. 1968.

${ }^{6}$ Архив Војводине, фонд 334, Записник са Проширене седнице Председништва и Извршног комитета Покрајинског комитета од 11. 6. 1968.
} 
буду организатори скупова студената, да иду у сусрет догађајима да се надовежу на све што је позитивно у студентским демонстрацијама у Београду и да то узму као основни повод за разговор са студентима, како би они били и укључени у општи покрет студентске омладине у Београду и како се не би од њега изоловали, како би се укључили у онај део целокупних кретања који је значио један позитиван притисак на решавање отворених проблема студената и проблема нашег друштва, а како истовремено форме и облици тога учествовања не би довели до оних негативних и непријатних и неприхватљивих појавних облика какви су карактерисали прве кораке демонстрација у Београду када је, као што се зна, било и жестоких интервенција милиције и материјалних штета итд“.

Тепавац је оценио да је на студентским скуповима по војвођанским градовима до изражаја дошло „расположење и све политичке карактеристике које су везане и за београдску средину“, са једном битном разликом: организованост партијских кадрова у Војводини успело је каналисати те појаве, „брже и успешније скоро у свим случајевима реаговати на њих, имати на уму и регистровати их“. Том приликом Мирко Тепавац је одао признање комунистима и „прогресивним људима“ на Универзитету, студентима и професорима, што су успели „да доста брзо изађу на крај са оним екстремним елементима и оним екстремним настојањима која су хтела да вуку ствари у правцу лево и десно од основног правца кретања целе политичке акције у Београду“. Навео је да је међу студентима било гледишта која су била обојена „црвеногардејским и Мао Цетунговским концепцијама и погледу као што смо имали и као што су дошле до изражаја и ове либерално лабуристичке, прођиласовске и проранковићевске и друге, укључујући, разуме се, и оне екстреме, и оне који су наступали са чисто непријатељских позиција у најдиректнијем смислу речи, чак и непозивајући се на социјализам - којих је, може се рећи, код нас било минимално у односу на оно што се дало регистровати у Београду“.

Оценивши да је „Титов говор смирио целу буру и дао једну политичку оцену збивања, што је сада основа за регулисање ситуације у Београду и очигледно врло успешно и врло ефикасно, захваљујући и великом престижу Председника и његовом правом начину да се надовеже и ослони на све што је прогресивно у захтевима и хтењима омладине, студената и професора“, упозорио је да тиме нису сви проблеми решени и да је задатак покрајинског руководства да почне решавање „свих оних ствари које се тичу радника и положаја произвођача а које леже у нашој моћи, иако разуме се основни део свих тих проблема не лежи у нашој моћи за решавање, већ зависе од крупнијих регулативних потеза које морају да начине савезне и републичке институције“. Уједно је напоменуо да је то закључак и „ужег састава“ ИК и Председништва, оних чланова тих тела који су живели у Новом Саду, а који су се већ били састајали претходних дана, те да је ПК на сложеност економске и политичке ситуације упозоравао и пре јуна месеца.

У наставку седнице дискутовали су представници Универзитета, Савеза студената и других органа. Пера Зубац је присутне обавестио „о политичкој акцији коју је водио Савез студената у заједници са СК на Универзитету од првог дана догађаја на Београдском универзитету“. Већ прво вече немира у Београду заједно је заседао Универзитетски комитет и Савез студената али „тада још није могла да се 
да прва оцена јер је штампа, као што знате, доста парцијално и доста погрешно просудила целу ствар“. Стога је одлучено да се седница одложи до следећег послеподнева, с тим да се претходно разговара „са одговарајућим функционерима у Београду који треба да дају праву слику и оцену“. Пера Зубац је са поносом истакао да је Председништво Савеза студената и Универзитетски комитет СК, саопштењем објављеним другог дана протеста око подне, реаговало прво у Југославији, „ако изузмемо реаговање Ниша које је у суштини било погрешно јер су другови у Нишу осудили целу акцију сматрајући да се ради о групи хулигана“.

На другом састанку наведени форуми су одлучили да иду „у сусрет догађајима, да нас не изненади било каква група и било каква линија која можда постоји, ми смо и на то рачунали, и која ће можда инсистирати да се ради другачије него што би ми то хтели и него што би било нормално за СК“. Конкретно, руководиоци Савеза студената су посетили четири студентска дома, са намером да испитају „да ли студенти још увек прихватају ово руководство, да ли прихватају наше ставове“. Зубац је сведочио да је горе поменуто саопштење Савеза студената на зборовима студената по домовима једногласно прихваћено, а сами зборови „прошли су по нашој оцени јако добро, све могуће екцесе, екцесна понашања сами другови у домовима су осујетили“. Као чињеницу од нарочитог значаја истакао је да нису оклевали да изађу пред све студенте, без претходног састанка са комунистима међу њима.

Следећег дана одржан је збор на Филозофском факултету, а уследили су зборови на свим факултетима и вишим школама. Сами студенти изјаснили су се да не треба излазити на улице, већ да акцију треба водити „на један достојанствен и крајње разуман начин“. Руководиоци Савеза студената су на свим зборовима добили подршку својих колега, осим на Филозофском факултету, где им је у једном тренутку изгласано неповерење, студенти су се свуда држали мирно а „неки појединци који су покушали да праве панику и изазову друге студенте на улицу били су спречени на многим факултетима од стране самих студената“, што је све давало разлога за задовољство, закључио је Пера Зубац.

У наставку је говорио ректор Новосадског универзитета, ${ }^{7}$ који је известио да је одржао састанак са деканима на коме је констатовано „да је поред интензивне акције СК за овакав исход било најважније то што је постојало јединство између студената, већине студената и Универзитета, мислим и наставника да смо имали изванредно добру везу са студентском организацијом, да смо конкретним мерама учинили доста и у границама наших могућности да побољшамо њихово стање“. Да би се то јединство очувало, сматрао је ректор, морало је да дође до одређених промена. Као прво, било је потребно интензивирати рад на Статуту универзитета, како би се он што пре донео. Навео је и проблем ванредних студената те потребу успоставе нових критеријума око пријема студената, будући да постојећи „онемогућују утицај на већи пријем из радничких породица“.

\footnotetext{
${ }^{7}$ Ректор Универзитета у Новом Саду, коме се у цитираном записнику не наводи име, од 1967. до 1971. године био је проф. Драгољуб Димковић. Енциклопедија Новог Сада, 29, 203.
} 
Антун Миладиновић из Суботице је указао на специфичности студентских протеста у том граду. Навео је да је руководство основне организације СК и Савеза студената, по сазнању да су студенти заказали збор за 4. јун, предложило да се тај скуп одложи неколико сати ,да би добили у времену - с обзиром да је било мишљења да не треба вршити никакве припреме него пустити ствари стихији, да је било и таквих мишљења и захтева да се изађе на улице, 'да се чује глас' итд“. У томе су и успели, али збор на Економском факултету, пред 500 учесника, ипак није протекао у потпуности мирно. Било је „четири до пет екстремних иступања“, за шта је Миладиновић кривио „амбасадоре - представнике са Економског факултета у Београду који су дошли да као учесници београдског покрета 'објасне читаву ствар'“. И поред захтева да се иде на улице и да се демонстрира, студенти су се ипак пред поноћ разишли „као из позоришта“. У случају неког другог исхода, Миладиновић и други руководиоци су се обезбедили тако што су ангажовали 400 до 500 комуниста из радних организација „који би изашли напоље да успоставе равнотежу између евентуалних испада, да не бисмо укључивали полицију“. Према сведочењу говорника, већ у половини збора, видевши да се ствари одвијају у мирном правцу, распустили су ову групу која је била ангажована наводно „не зато да се туку са студентима ако евентуално изађу на улице него да иду са њима и да каналишу демонстрације“.

Оправдање за овакву меру Миладиновић је нашао и у потреби да се онемогући „инфилтрирање неких страних елемената који би излазак на улице злоупотребили јер смо имали јако појачану посету страних туриста, дипломатског кора итд“. Већ сутрадан ситуација се значајно променила, на збору студената виших школа пружена је пуна подршка политици СК, испити су се одвијали редовно, није било никаквих исписаних парола и сл. Представницима студената је било дозвољено да посете радне организације, како би обавестили раднике о својим захтевима. Није било екцеса те „нисмо сматрали за потребно да држимо никакве митинге у радним организацијама да евентуално не бисмо још више узнемирили духове“, завршио је своје излагање представник суботичких комуниста.

У наставку седнице професор Александар Фира је изразио задовољство што je „90\%, ако хоћете, студената Новосадског универзитета и у овој акцији показало као омладина која је несумњиво опредељена за социјалистички развитак и самоуправљање и која и овом својом акцијом покушава - друго је питање оцена да ли у сваком иступу на најбољи могући начин, кроз најбоља могућа средства, али која жели друштвени ангажман не само у решавању својих питања него и у решавању питања развитка југословенског социјализма у целини“. Сматрао је да је за то највише заслужна добра координација између покрајинских и градских политичких руководстава и Универзитета, те се заложио да се тај „непосредан однос“" настави и интензивира, и то низом састанака и конференција. На Фирино излагање надовезао се Пера Зубац, предочивши програм рада руководства Савеза студената Новосадског универзитета током летњег распуста.

Сима Дујин је реферисао о догађајима у Зрењанину, где је студирало око 1000 студената на две више школе. Прва процена локалног руководства била је да нема разлога да се очекују „екцесне ситуације“ међу зрењанинским 
високошколцима, али нису одбацили могућност да ситнијих инцидената буде „с обзиром на несређеност и лоше објективно стање у студентском дому, лоше услове у којима се налази“. Стога је формирана заједничка комисија од представника студената, професора и радног колектива дома, која је имала задатак да утврди „списак проблема и начин њиховог решавања“. У разговору са студентима нису били истакнути захтеви за организовањем зборова или уличних демонстрација, осим од стране пар њих. Мада се нису слагали са начином протеста београдских студената, зрењанински су ипак подржали њихове захтеве, а изнели су и сопствена негативна искуства везана за „однос наставника и професора према студентима“. Када се једног јутра у дому појавила „парола непријатељске садржине: доле социјализам“, студенти су сами пријавили починиоца - „управо да се ради о једном студенту са групе физичког васпитања, да је то онај исти студент који је захтевао демонстрације“. Дујин је стога изразио оптимизам у погледу даљег развоја ситуације у свом граду.

Илија Рајачић је решење свих проблема видео у убрзању процеса „стварног развоја самоуправних односа на Универзитету и стварање услова да се тај студентски механизам укључи у решавање свих битних проблема на Универзитету и у свим нашим друштвеним процесима“. Скренуо је пажњу и на то да студентска популација уочава појаве неоправданог богаћења у друштву, што је апострофирано и на неким зборовима, те је, по његовом мишљењу, будућа акција комуниста морала ићи у том правцу. И Мате Пижурица је, у име Универзитетског комитета, позвао да се „преко акција конкретних постигне политичко оздрављење“. Међу осталим дискусијама издвајала се она Душана Алимпића, који је искористио прилику да се осврне на незавидну економску ситуацију у Војводини.

Изводећи закључке на самом крају, Мирко Тепавац је као најважнији резултат целе расправе истакао чињеницу да „Председништво и ИК поздрављају и подржавају ставове које је изнео Председник Тито у свом говору и који ће доћи до изражаја сигурно и у Смерницама које ће се за извесно време појавити у јавности, jep је сигурно да унутар та два јавна политичка акта неће бити унутрашњих контрадикција нити разлика“. Уочио је да су се отвориле нове могућности деловања и ширења утицаја СК, користећи „порасло политичко интересовање код омладине и студената“. На то су их, тврдио је Тепавац, обавезивале и речи самог Тита. Као посебно позитивну ствар изнео је да су на подручју Новосадског универзитета „у арени до краја ипак остали, у основи, само социјалистичке идеје и програми, а да су остали одбачени“. По његовој оцени, студентски протест се одвијао у „мирнијим и организованим облицима“, и поред покушаја појединаца да се изазову екцесне ситуације. На то су комунисти са Новосадског универзитета, по њему, требали да буду поносни и да не подлегну наметању комплекса названог „редуцирана револуционарност, као да би та прогресивност била већа уколико би били екцеснији или бурнији облици његовог изражавања“. Тепавац је нагласио да је током тих неколико дана дошло до изражаја ,једно значајно политичко јединство“ Градског, Покрајинског и Универзитетског комитета, а није заборавио да похвали ни Службу унутрашњих послова, која се „код нас држала хладнокрвно и да је била у пуној мери политички повезана са политичким потезима који су чињени на Универзитету, у 
Комитету и другим организацијама, и да је то такође једна околност која је омогућила да се на извесним разликама у дејству и у погледима не формира једно противуречно стање које би могло да доведе у неким случајевима сигурно и до непријатних политичких последица с којима би после имали проблеме“. 


\title{
THE STUDENTS' PROTEST AT THE UNIVERSITY OF NOVI SAD IN JUNE 1968
}

\begin{abstract}
Summary
The tumultuous protests that engulfed the student population in 1968 all around the World, did not evade the socialist Yugoslavia. First the Belgrade students, and then the students from all the other Yugoslav Universities went on strike and identified the requirements for more equitable social relations. University of Novi Sad was on the sidelines of events in this large protest movement, during the first decade of June 1968. Conferences that were held at the faculties and university dormitories within the University of Novi Sad were of a less protest nature. They were organized more for the purpose of solidarity with Belgrade colleagues, and tranquilized by the measures taken by the communist government. A number of "incidents" was very small. Such characteristics of the students' movement in Novi Sad were a result of the well-organized action taken by the highest party forums in Vojvodina, as it could be seen from the minutes of the PK meeting.
\end{abstract}

Keywords: 1968, University of Novi Sad, the League of Communists, students. 